\title{
EVALUATION OF THREE ACARICIDES COMPARED WITH PREDATORY INSECT AGAINST PANONYCHUS ULMI ON APPLE TREES
}

\author{
HASSAN, M. F. ${ }^{1}$, S. S. EL- BADAWY ${ }^{2}$, A. A. EL-SHERIF ${ }^{1}$ and M. G. DRAZ ${ }^{2}$ \\ 1. Zoology and Agric. Nematology Dep., Faculty of Agriculture, Cairo University. \\ 2. Plant Protection Research Institute, ARC, Doki, Giza, Egypt.
}

(Manuscript received 12 November 2015)

\begin{abstract}
$\mathrm{E}$ fficacy of three acaricides (Ortus 5\% EC, Milbeknock 1\% EC and Cascade 10\% DC) and predatory insect; Chrysoperla carnea Stephens was evaluated on the European red mite Panonychus ulmi Koch (Acari: Tetranychidae) movable stages infested apple orchards during the two successive seasons; 2012 and 2013 at Darawa village, Ashmon, Menoufia governorate, as well as determining the biochemical changes in the treated insects. The results show that, The highest reduction percentages of $P$. ulmi movable stages during 2012 and 2013 seasons were recorded with Ortus followed by Milbecknok then the predatory insect; $C$. carnea, while the lowest reduction percentages were recorded with Cascade. The effect of the two acaricides Ortus and Milbecknok (the highest toxic acaricides) on the major biochemical components of $P$. ulmi adult females showed that, the acaricide Ortus achieved high effects on the total lipids content and the two enzymes Acetylcholinesterase (AchE) and Glutathione-S-transferase (GST). The acaricide Milbecknok recorded high effects on the total lipids and carbohydrates contents and lipase, trehalase, amylase, AchE and GST enzymes. The two acaricides Ortus and Milbecknok are effective in controlling European red mite on apple trees and this can be attributed to abnormal changes of the major biochemical components in the treated mites. The predatory insect; $C$. carnea has efficient predation against $P$. ulmi and resulting increasing in the reduction of mite populations.
\end{abstract}

Keywords: Apple, acaricides, toxicity, Chrysoperla carnea, Panonychus ulmi, biochemical changes.

\section{INTRODUCTION}

Apple Malus domestica Borkh. (Family: Rosaceae) is one of the most common crops in the world. It preferred by consumers and considers an economic crop that has a high rank locally. Worldwide, apple production reaches about 58 billion tons at each year. In Egypt, an average productivity of apple decreased from 557944 to 541000 tons during 2007 and 2012, respectively, (the Annual Report of Agric. Statistics Dept., Ministry of Agriculture, Egypt. Apple infested with several pests including European red mite Panonychus ulmi Koch (Acari: Tetranychidae) which from the most destructive mites in apple orchards (Prokopy and Croft, 1994). 
The acaricides in controlling mite pests were succeeded in different orchards and field crops and also, predators are using a bio-control agent for controlling the mite pests (Jeyarani et al., 2012). Many studies on the acaricides are needed to evaluate their effects on the biochemical changes of treated insects. The present work was conducted to study effect of releasing predatory insect, Chrysoperla carnea Stephens and spraying of acaricides; Ortus 5\% EC, Milbeknock 1\% EC and Cascade $10 \%$ DC to control P. ulmi movable stages on apple trees during two successive seasons 2012 and 2013 and evaluated the efficacy of acaricides by determining the biochemical changes in the treated adult females of the mites.

\section{MATERIALS AND METHODS}

\section{Site of study:}

An orchard located at Darawa village, Ashmon, Menoufia governorate was chosen to conduct these experiments during the two successive seasons; 2012 and 2013. Orchard divided as a Complete Randomized Blocks Design to 4 blocks every block contain 5 experimental units (15tree/unit). A row of trees separates between the experimental units, the distances between trees $(3 \mathrm{~m} \times 3 \mathrm{~m})$ every treatment contain four replicate.

\section{Predator and acaricides:}

Predatory insect; C. carnea was released as biological control agent and obtained from the Applied Center for Biological Control, Faculty of Agriculture, Cairo University, It was stored in ice box at $\left(10^{\circ} \mathrm{C}\right)$ before one day of the application. Trade name, common name, formulation and rate of application of the three acaricides; Ortus 5\% EC (Fenpyroximate), Milbeknock 1\% EC (Milbermectin) and Cascade 10\% DC (Flufenoxuron) are tabulated in Table (1).

\section{Release of $\boldsymbol{C}$. carnea and spraying of the acaricides:}

The application of release was started when the population of $P$. ulmi reached 3mite/leaf. Release started on $22^{\text {th }}$ April during 2012 season, and on $29^{\text {th }}$ March during 2013 season (40larva/tree). The propagation of predator was in early morning on trees (40 larva/tree). The ratio between predator and prey was 1:75. The cultivated Apple trees received all normal agricultural processes without using acaricides. The experimented area was divided into four treatments and check according to complete randomized block design, each treatment was contained four replicates.

The application of acaricides was started on May $3^{\text {rd }}$ at the first season and on April $9^{\text {th }}$ at the second season. Check treatment was sprayed with water only. A compressor spryer (600 liters capacity) was used. Samples (20 leaves) were taken 
randomly from each replicate, just before spraying then weekly afterwards. Samples were carefully examined and the numbers of alive moving stages of $P$. ulmi were recorded. An additional spray was conducted after three weeks of the first spray because of the increase of $P$. ulmi population.

\section{Biochemical assays:}

\subsection{Determination of total proteins, carbohydrates and lipids:}

Protein content of $P$. ulmi samples was estimated spectro-photometrically by the method of Bradford (1976). Carbohydrates content was determined according to Dubois et al., (1956). Total lipids were determined according to Knight et al., (1972). Total proteins, carbohydrates and lipids contents were calculated and expressed as $\mathrm{mg} / \mathrm{g}$ of mite body weight.

\section{4,2. Digestive enzymes assays (Protease and lipase):}

The proteolytic activity of $P$. ulmi was determined according to Birk, et al., (1962). The proteolytic activity was determined from bovine serum albumin standard curve; as O.D. units $\times 10^{3} /$ P. ulmi body weight. Lipase activity was determined by the method of Tahoun and Abdel Ghaffar (1986). Lipase unit was defined as the number of $\mu$ g oleic acid liberated/min.

\subsection{Carbohydrate hydrolyzing enzymes assays:}

The activity of carbohydrate hydrolyzing enzymes (trehalase, amylase, and invertase) was determined according to method of Birk et al., (1962). The optical density (OD) was measured at $550 \mathrm{~nm}$ using spectrophotometer.

\subsection{Acetylcholinesterase determination:}

Acetylcholinesterase (AchE) activity was measured according to the method of Simpson et al. (1964). The decrease in AchBr resulting from hydrolysis by AchE was read at $515 \mathrm{~nm}$.

\subsection{Glutathione-S-transferase (GST) determination:}

Glutathione S-transferase (GST) could be detected as described by the method of Habig et al., (1974). The absorbance at $340 \mathrm{~nm}$ was recorded against blank to determine the nanomole substrate conjugated/min/larva using a molar extinction coefficient of $9.6 / \mathrm{mM} / \mathrm{cm}$.

\section{Statistical analysis}

Level of significance using Fisher's least significant difference (LSD). Using the Statistical Analysis System. Reduction percentages of the P. ulmi were calculated according to Henderson and Tilton (1955). 


\section{RESULTS AND DISCUSSION}

\section{Reduction percentages of P. ulmi on apple trees during 2012 and 2013 seasons.}

Data presented in Table (2) and Fig. (1) showed that, the reduction percentages of $P$. ulmi movable stages after three days of releasing $C$. carnea and spraying acaricides; Ortus, Milbecknok and Cascade were averaged 43.60, 71.40, 67.10 and $47.50 \%$ during 2012 season, respectively; while during 2013 season, it averaged $58.90,74.30,74.00$ and $39.20 \%$, respectively. The reduction percentages after six days of releasing of $C$. carnea and spraying acaricides; Ortus, Milbecknok and Cascade increased to reach $65.90,85.10,77.70$ and $60.80 \%$ during 2012 season, respectively; while during 2013 season the reduction percentages averaged 79.10, $87.40,81.20$ and $54.70 \%$ for the previous treatments, respectively. After nine days of spraying acaricides, the population of $P$. ulmi was increased in apple treated by Ortus and Milbecknok, so the reduction percentages were decreased to 82.20 and $77.00 \%$ during 2012 season, respectively, also, the population of 2013 season increased after nine days of spraying acaricides Ortus, Milbecknok and Cascade, so the reduction percentages were decreased they recorded $75.00,75.50$ and $61.10 \%$, respectively. It was due to new hatching of $P$. ulmi eggs.

After four days from the second spray, the highest reduction percentages of $P$. ulmi was recorded with Ortus (95.50\%); while Milbecknok and Cascade were recorded 85.70 and $71.80 \%$ during 2012 season, respectively, but during 2013 season the reduction percentages of $P$. ulmi were recorded with $C$. carnea, Ortus, Milbecknok and Cascade $81.80,87.10,84.00$ and $59.00 \%$, respectively. The highest mean reduction percentages affected by predatory insect; $C$. carnea and three acaricides during 2012 and 2013 seasons were recorded with Ortus averaged 85.57 and $84.18 \%$, respectively, followed by Milbecknok averaged 80.77 and $81.63 \%$ then the predatory insect; C. carnea averaged 75.19 and $78.52 \%$, respectively; while the lowest reduction percentages were recorded with Cascade averaged 60.29 and 54.43\%, respectively. Several studies have shown the effectiveness of acaricides against mites and other insects. Rana and Bhardwaj (2004) found that, the acaricides; fenpropathrin, fenazaquin and monocrotophos managed the $P$. ulmi population effectively up to 21 days after spraying. However, fenazaquin kept the mite population below economic threshold level ( $<5$ mites per leaf) even up to 28 days after spraying. Abou El-Ela, (2014) reported that, two of acaricides, Challenger and Ortus were markedly more efficient in reducing the Tetranychus urticae Koch than Vertimec, Delmite and Bioca where they produced $81.55 \%$ and $80.62 \%$ reduction of $T$. urticae 
in average within 3, 7, 14 and 21 days after spraying at early season (2007), respectively. The similar trend of these results was observed in the second season (2008). The toxic effect of acaricides to mites depends on the chemistry of acaricides, their rates, microclimatic conditions, the development stages of mites. Larvae of $C$. carnea consumed a mean of 24.9 and 23.7 nymphs of $P$. ulmi and T. urticae, respectively. The mean total number of preys consumed by $C$. carnea was 396.7 and 379.4 movable stages of $P$. ulmi and T. urticae, respectively. C. carnea also consumed significant numbers of Typhlodromus pyri Scheuten nymphs (4.3/day) and adults (6.9/day), also, suggesting that $C$. carnea is also a hyper predator, (Khan et al., 2004).

\section{Biochemical assays:}

The efficacy of two acaricides Ortus and Milbecknok on adult females of $P$. ulmi were investigated by estimated main energy reserve substances and seven representative enzymes.

\subsection{Determination of total proteins, carbohydrates and lipids (Main energy reserves):}

The obtained results in Table (3) showed that, there are significant effect of the acaricide Ortus against the total protein content of the adult females of $P$. ulmi as compared with control where it decrease the total proteins value from 35.67 to 29.93 ( $\mathrm{mg} / \mathrm{g}$ fresh body weight), while no significant difference (35.67 to $36.67 \mathrm{mg} / \mathrm{g}$. b.wt) was observed in the total protein content treated with the other acaricide Milbecknok as compared with control.

The effects of Ortus and Milbecknok on total carbohydrate content were summarized in Table (3). Total carbohydrate content was significantly reduced by Milbeknock (Control value decreased from 12.93 to $7.63 \mathrm{mg} / \mathrm{g}$.b.wt) and the other acaricide Ortus had no significant effect. Also, a significant reduction in the amount of lipid content was observed in the adult females of $P$. ulmi treated with Milbeknock (from 8.13 to $5.37 \mathrm{mg} / \mathrm{g}$ fresh body weight) as compared with control, but not significant reduction in case of Ortus (from 8.13-7.97 mg/g b.wt).

The results of the acaricide Ortus are agreement with Behroozi Moghadam et al., (2011) reported that chlorfluazuron and pyriproxyfen did not affect total carbohydrate and lipid contents in white leaf borer, Ocneria terebinthina Strg. Megahed et al., (2013) showed that the total protein of Spodoptera littoralis treated with certain acaricides (Emamectin benzoate "Proclaim", abamectin "Romacten" and spinosad "Tracer") is significantly decreases about five times compared to that of control. The results of the acaricide Milbecknok confirmed by Elbarky et al., (2008) the 
effect of Radiant SC12\% (Spinetoram) on larval instars of S. littoralis showed that, the amount of total carbohydrates and total proteins were significantly decreased. Also, Alimohamadi et al., (2014) found that significant reduction in the amount of lipid content was observed in spirodiclofen-treated larvae of the ladybird beetle, Hippodamia variegata. The decrease of the total protein in may reflect the decrease in the enzymatic activities of various enzymes. A diminution in the rate of ATP synthesis and inhibition of RNA synthesis are also the main causes of decreased total protein content (Nabih et al., 1990). Regarding the total lipid content, a number of toxic agents have been found to cause disturbances of fats in different body organs of both vertebrate and invertebrate animals.

\subsection{Determination of enzymes:}

\section{Digestive enzymes (protease and lipase)}

The obtained results in Table (4), showed that, there are non significant effects of the tow acaricides Ortus and Milbeknock on protease activity of $P$. ulmi adult females treated and non treated. Acaricide Milbeknock decrease lipase enzyme activity from 46.7 to 29.17 ( $\mu \mathrm{m}$ olec acid/min/g.b.wt), while the other acaricide Ortus had no significant effect. These results are agreement with Zera and Zhao (2004) showed that, methoprene caused reduction in lipase enzyme activity and lipid metabolism in Gryllus firmus. Spiromesifen, acts as an inhibitor of a lipid metabolism enzyme, in contrary, Spirodiclofen increases lipase enzyme activity and consequently lipid metabolism resulting decrease in lipid content Alimohamadi et al., (2014). Decreasing of lipase activity tend to disturbance in the vital process of the tested mite, this is because lipids are the most suitable reserves for storage of energy. Compared to carbohydrates, lipids can supply as much as eight times more energy per unit weight (Beenakkers et al., 1985).

\section{Carbohydrate hydrolyzing enzymes}

Data illustrated in Table (5) exhibited that, non significant effect on enzyme activity of invertase, trehalase and amylase enzymes with Ortus. The other acaricide Milbeknock achieved high significant effect on trehalase and amylase activities, where it decreased the values of from 118 to 73.67 and 70 to 46.33 ( $\mu \mathrm{g}$ glucose/min/g.b.wt) respectively, while, Milbeknock have non significant effect on invertase enzyme. However, activities of the carbohydrate hydrolyzing enzymes, amylase, invertase and trehalase were reduced in adult females after treatment with Milbecknok, compared with control. These data of acaricide Milbecknok, approximately are consist with results reported by Elbarky et al., (2008) the effect of Radiant SC12\% on larval instars of $S$. littoralis after 24 hours showed that, the hydrolyzing enzymes (invertase, trehalase and amylase), were significantly decreased compared to control. 


\section{Detoxification enzymes (AchE and GST enzymes)}

The obtained results in Table (6), showed that, both of acaricides Ortus and Milbeknock have effect on the activities of two enzymes. Ortus significantly elevated activity of the AchE from 122.33 to 176.67 ( $\mu \mathrm{g} \mathrm{AchBr/min/g.b.wt),} \mathrm{but} \mathrm{decreased} \mathrm{the}$ activity of GST enzyme from 162.67 to 73.33 (mmol.Sub. conjugated/min/g.b.wt). The other acaricide Milbeknock has slight increase in AchE activity from 122.33 to 136.67 ( $\mu \mathrm{g} \mathrm{AchBr} / \mathrm{min} / \mathrm{g}$. b.wt), while the activity of GST enzyme decreased from 162.67 to 97.33 (mmol. Sub. conjugated/min/g.b.wt). These results confirmed by Elbarky et al., (2008) the activity of acetylcholineestrase larval instars of S. littoralis treated spinosyn was significantly increased compared to control. However, our results disagree with results obtained by Loucif-Ayad et al. (2008) the acaricides used to control the parasitic mite Varroa destructor (Acari, Varroidae) did not affect the activity of AChE, but It is possible that highly doses of acaricides will elicit AChE activity decrease.

Our results of GST enzyme are agree with the findings of Itabajara et al., (2004) who found that, the tested acaricides and insecticides (Ethion, amitraz, diazinon, chlorpyrifos, DDT, cypermethrin, ivermectin, deltamethrin and flumethrin) inhibit Boophilus microp/us GST activity in 12-34\% compared to control group, except for ivermectin, which does not inhibit GST and activity of GST is sensitive to various compounds used in commercial acaricides. In contrast, results of Loucif-Ayad et al., (2008) indicated that treatments with acaricides led to increased GST activity in the larvae and pupae of bees compared with the control.

\section{CONCLUSIONS}

The two acaricides Ortus and Milbecknok are effective in controlling European red mite $P$. UImi on apple trees. Substantial biochemical events in adult females are involved in responding to the action of these two acaricides. The predatory insect $C$. carnea release proved to be efficient in reducing $P$. ulmi movable stages population; therefore, the study recommends the use of this predator with integrated pest management programs (IPM) in controlling P. ulmi to reduce the using of chemical pesticides. 
Table 1. Data of three acaricides which tested against $P$. ulmi on apple trees.

\begin{tabular}{|l|c|c|c|}
\hline Trade name & Active ingredient(s) & Chemical class of AI(s) & Rate of application \\
\hline Ortus 5\% EC & Fenpyroximate & Pyrazole & $50 \mathrm{~cm}^{3} / 100 \mathrm{~L}$ water \\
\hline Milbeknock 1\% EC & Milbermectin & Avermectin & $75 \mathrm{~cm}^{3} / 100 \mathrm{~L}$ water \\
\hline Cascade 10\% DC & Flufenoxuron & Benzoylurea & $60 \mathrm{~cm}^{3} / 100 \mathrm{~L}$ water \\
\hline
\end{tabular}

Table 2. Reduction percentages of $P$. ulmi movable stages on apple affected by predatory insect; C. carnea and three acaricides during 2012 and 2013 seasons.

\begin{tabular}{|l|c|c|c|c|}
\hline \multirow{2}{*}{ Sampling date } & \multicolumn{4}{|c|}{ Reduction percentages of $P$. ulmi movable stages /leaf } \\
\cline { 2 - 5 } & C. carnea & Ortus & Milbecknok & Cascade \\
\hline $06 / 05 / 2012$ & 43.6 & 71.4 & 67.1 & 47.5 \\
\hline $09 / 05 / 2012$ & 65.9 & 85.1 & 77.7 & 60.8 \\
\hline $12 / 05 / 2012$ & 85.3 & 82.2 & 77.0 & 70.6 \\
\hline $17 / 05 / 2012$ & 84.6 & 95.5 & 85.7 & 71.8 \\
\hline $22 / 05 / 2012$ & 80.6 & 90.6 & 86.9 & 55.5 \\
\hline $27 / 05 / 2012$ & 77.6 & 89.0 & 87.7 & 51.7 \\
\hline $02 / 06 / 2012$ & 88.7 & 85.2 & 83.3 & 64.1 \\
\hline Mean & $75.19 \mathrm{~b}$ & $85.57 \mathrm{a}$ & $80.77 \mathrm{a}$ & $60.29 \mathrm{c}$ \\
\hline LSD at 0.05 & & 11.4 & & 39.2 \\
\hline $12 / 04 / 2013$ & 58.9 & 74.3 & 74.0 & 54.7 \\
\hline $15 / 04 / 2013$ & 79.1 & 87.4 & 81.2 & 61.1 \\
\hline 20/04/2013 & 81.1 & 75.0 & 75.5 & 59.0 \\
\hline 25/04/2013 & 81.8 & 87.1 & 84.0 & 57.7 \\
\hline 30/04/2013 & 82.4 & 88.9 & 87.4 & 54.9 \\
\hline $05 / 05 / 2013$ & 87.8 & 92.4 & 87.7 & $54.43 \mathrm{~b}$ \\
\hline Mean & $78.52 \mathrm{a}$ & $84.18 \mathrm{a}$ & $81.63 \mathrm{a}$ & \\
\hline LSD at 0.05 & & 13.5 & & \\
\hline
\end{tabular}

Table 3. Effect of two acaricides on total proteins, carbohydrates and lipids of $P$. ulmi adult females.

\begin{tabular}{|c|c|c|c|}
\hline \multirow{2}{*}{ Acaricides } & \multicolumn{3}{|c|}{ P. ulmi main energy reserves (mg/g.b.wt) } \\
\cline { 2 - 4 } & Total proteins & Total carbohydrates & Total lipids \\
\hline Ortus 5\%EC & $29.93 \mathrm{~b}$ & $12.93 \mathrm{a}$ & $8.13 \mathrm{a}$ \\
\hline Milbeknock 1\% EC & $36.67 \mathrm{a}$ & $11.33 \mathrm{~b}$ & $7.97 \mathrm{a}$ \\
\hline Control & $35.67 \mathrm{a}$ & $7.63 \mathrm{c}$ & $5.37 \mathrm{~b}$ \\
\hline F value & $22.375^{* *}$ & $73.090^{* * *}$ & $26.74 * * *$ \\
\hline LSD 0.05 & 2.650 & 1.100 & 1.038 \\
\hline
\end{tabular}


Table 4. Effect of two acaricides on protease and lipase enzymes of $P$. ulmi adult females.

\begin{tabular}{|c|c|c|}
\hline \multirow{2}{*}{ Acaricides } & \multicolumn{2}{|c|}{ Enzyme activity } \\
\cline { 2 - 3 } & Protease & Lipase \\
& O.D. units $\times 10^{3} /$ g.b.wt. & $\mu$ oleic acid liberated/min/g.b.wt. \\
\hline Ortus 5\%EC & $29.93 \mathrm{~b}$ & $12.93 \mathrm{a}$ \\
\hline Milbeknock 1\% EC & $36.67 \mathrm{a}$ & $11.33 \mathrm{~b}$ \\
\hline Control & $35.67 \mathrm{a}$ & $7.63 \mathrm{c}$ \\
\hline F value & $22.375^{* *}$ & $73.090 * * *$ \\
\hline LSD 0.05 & 2.650 & 1.100 \\
\hline
\end{tabular}

Table 5. Effect of two acaricides on carbohydrate hydrolyzing enzymes of $P$. ulmi adult females.

\begin{tabular}{|c|c|c|c|}
\hline \multirow{2}{*}{ Acaricides } & \multicolumn{3}{|c|}{ Enzyme activity $(\mu \mathrm{g}$ glucose/min/g.b.wt) } \\
\cline { 2 - 4 } & Invertase & Trehalase & Amylase \\
\hline Ortus 5\%EC & $412.00 \mathrm{~b}$ & $128.33 \mathrm{a}$ & $78.33 \mathrm{a}$ \\
\hline Milbeknock 1\% EC & $436.33 \mathrm{a}$ & $73.67 \mathrm{~b}$ & $46.33 \mathrm{~b}$ \\
\hline Control & $424.00 \mathrm{ab}$ & $118.00 \mathrm{a}$ & $70.00 \mathrm{a}$ \\
\hline F value & $8.415^{*}$ & $84.658^{* * *}$ & $45.37 * * *$ \\
\hline LSD 0.05 & 14.514 & 10.923 & 8.528 \\
\hline
\end{tabular}

Table 6. Effect of two acaricides on AchE and GST enzymes of $P$. ulmi adult females.

\begin{tabular}{|c|c|c|}
\hline \multirow{2}{*}{ Acaricides } & \multicolumn{2}{|c|}{ Enzyme activity } \\
\cline { 2 - 3 } & $\begin{array}{c}\text { AchE } \\
(\mu \mathrm{gAchBr} / \mathrm{min} / \mathrm{g} . \mathrm{b} . w \mathrm{w})\end{array}$ & $\begin{array}{c}\text { GST } \\
(\mathrm{m} \mathrm{mol} . S u b . c o n j . / \mathrm{min} / \mathrm{g} . \mathrm{b} . w \mathrm{t})\end{array}$ \\
\hline Ortus 5\%EC & $176.67 \mathrm{a}$ & $73.33 \mathrm{~b}$ \\
\hline Milbeknock 1\% EC & $136.67 \mathrm{~b}$ & $97.33 \mathrm{c}$ \\
\hline control & $122.33 \mathrm{c}$ & $162.67 \mathrm{a}$ \\
\hline F value & $58.013 * * *$ & $137.409 * * *$ \\
\hline LSD 0.05 & 12.79 & 13.648 \\
\hline
\end{tabular}

Means with the same letter(s) are not significantly different. $(P<0.05)$

LSD = least significant difference. 

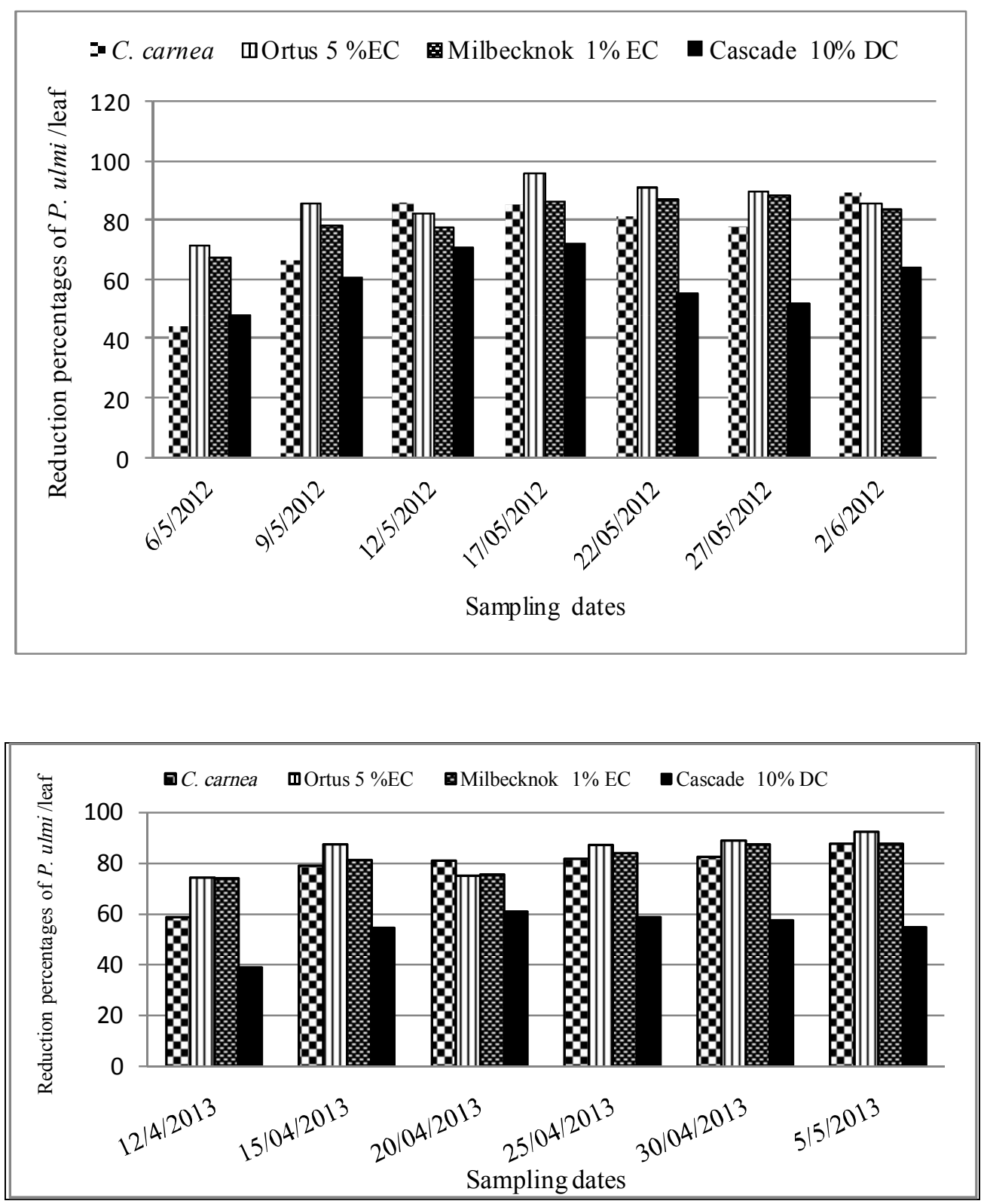

Fig. 1. Reduction percentages of $P$. ulmi movable stages on apple affected by predatory insect; C. carnea and three acaricides during 2012 and 2013 seasons. 


\section{REFERENCES}

1. Abou El-Ela A. A. 2014. Efficacy of five acaricides against the two-spotted spider mite Tetranychus urticae Koch and their side effects on some natural enemies. J. Basic and App. Zool., 67:13-18.

2. Alimohamadi, N.; A. Samih; H. Izadi and S. Noghabid 2014. Developmental and biochemical effects of hexaflumuron and spirodiclofen on the ladybird beetle, Hippodamia variegata (Goeze) (Coleoptera: Coccinellidae). J. Crop Prot. 3 (3): 335-344.

3. Beenakkers, A.T.; D. J. Vander and W. A. VAN Marrewijk 1985. Biochemical processes directed to flight muscle metabolism. In: G. A. Kerkut and L. Gilbert (eds.), Comparative Biochemistry and Physiology, 10:451-486.

4. Behroozi, M.; E. Izadi; H. Samih; M. A. Moharramipour and K. Mahdia 2011. Effect of insect growth regulators, temperature and overwintering on larvae of pistachio white leaf borer, Ocneria terebintina Stgr. (Lepidoptera: Lymantriidae). International J. of Agric. and Biol., 13: 375-380.

5. Birk, Y.; I. Harpaz; I. Ihasaya and A. Bondi 1962. Studies on the proteolytic activity of the beetles Tenebrio and Tribolium. J. Insect Physiol., 8:417-429.

6. Bradford, M. M. 1976. A rapid and sensitive method for the quantitation of microgram quantities of proteins utilizing the principle of protein-dye binding. Anal. Biochem., 72:248-254.

7. Dubois, M.; K.Gilles; J. Hamilton; P. Rebers and F. Smith 1956. Colorimetric method for determination of sugars and related substances. Analytical Chem. 28(3):350-356.

8. Elbarky, N, M.; H.F. Dahi and Y.A. El-sayed 2008. Toxicological evaluation and biochemical impacts for radient as a new generation of spinisyn on Spodoptera littoralis larvae. Egypt Acad. J. Biolg. Sci., 1(2): 85- 97.

9. Habig, W. H.; M. J. Pabst and W. B. Jakoby I974. Glutathione S-transferase. The first enzymatic step in mercapturic acid formation. J. Biol. Chem., 249:71307139.

10. Henderson, C. S. and Tilton, E. W. 1955. Test with acaricides against the brown wheat mite. J. Econ. Entomol., 48:157-161.

11. Itabajara S.; L. Tiago; M. André; F. Carlos; F. Daniela; T. Carlos and M. Aoi 2004. Effect of acaricides on the activity of a Boophilus microplus glutathione Stransferase. Veterinary Parasitology 119: 237-245.

12. Jeyarani S.; R. J. Singh and K. Ramaraju 2012. Influence of predator density on the efficiency of spider mite predators against two spotted spider Mite, 
Tetranychus urticae Koch (acari: Tetranychidae). Asian J. Biol. Sci. 5 (8): 432437.

13. Khan, I. A.; P. Blaeser and C. Sengonca 2004. Laboratory experiments on prey consumption by Typhlodromus pyri Scheuten (Acari, Phytoseiidae) and Chrysoperla carnea (Stephens) (Neuroptera, Chrysopidae) on different mite pests of apple and interactions between the two predators. Mitteilungen der Deutschen Gesellschaft fur allgemeine und angewandte, Entomologie, 14(1-6):377-380.

14. Knight, J.A.; S. Anderson and J.M. Rawle 1972. Chemical basis of the sulfophospho-vanillin reaction for estimating total serum lipids. Clin. Chem., 18: 199202.

15. Loucif-Ayad W.; N. Aribi and N. Soltani 2008. Evaluation of secondary effects of some acaricides on apis mellifera intermissa (hymenoptera, apidae): acetylcholinesterase and glutathione s-transferase activities. Eur. J. Sci. Res. 21(4):642-649.

16. Megahed M. M.; M.F. El-Tawil; M.M. El-Bamby and W.L. Abouamer 2013. Biochemical effects of certain bioinsecticides on cotton leaf worm, Spodoptera littoralis (Boisd.) (Lepidoptera: Noctuidae), Research J. Agric. \& Biol. Sci., 9(6): 308-317.

17. Nabih, L.; Z. El-Dardiri; A. El-Ansary and S. Ahmed 1990. Kinetic properties of two transaminases and lactate dehydrogenase in fresh water snails specific intermediate host for human schistosomiasis. Cell. Mol.Biol. 3:63-75.

18. Prokopy, R. J. and Croft, B. A. 1994. Apple insect pest management. Pages 543585 in R. L. Metcalf and W. H. Luckman, editors. Introduction to Insect Pest Management. John Wiley and Sons Ltd., New York 543-585.

19. Rana, V. K. and Bhardwaj, S. P. 2004. Bio-efficacy of acaricides against European red mite, Panonychus ulmi on apple (Malus domestica). Indian J. Agric. Sci., 74(11):628-630.

20. Simpson, D.R.; D. L. Bulland; and D. A. Linquist 1964. A semi-microtechnique for estimation of cholinesterase activity in boll weevils. Ann . Ent. Soc. Amer., 57: 367-371.

21. Tahoun, M.K. and Abdel-Ghaffar, M. 1986. A modified colorimetric method for assay of lipase activity. Alexandria Sci. Exch., 7: 235-244.

22. Zera, A. J. and Zhao, Z. 2004. Effect of a Juvenile hormone analogue on lipid metabolism in a wing polymorphic cricket: Implications for the endocrine biochemical bases of life history trade-offs. Physiol. Biochem. Zool. 77: 255-266. 


\title{
تقييم ثلاثة من المبيدات الأكاروسية وأحد المفترسات الحشرية ضد العنكبوت الأحمر الأوربي علي أثجار التفاح
}

\author{
مر اد فهمي حسن'، سامي سيد البدوي' ، أحمد عبدالله الثريف' ، محمد جمال دراز ' \\ ا ـ قسم الحيوان و النبماتولوجيا الزراعية- كلية الزراعة- جامعة القاهرة.

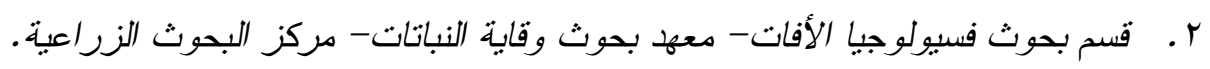

(Ortus 5\% EC, يهدف هذا البحث إلي تقييم ثلاثة أنواع من المبيدات الأكاروسية Milbeknock 1\% EC and Cascade 10\% DC) (Panonychus ulmi علي الأطوار المتحركة للعنكبوت الأحمر الأوربي Chrysoperla carnea

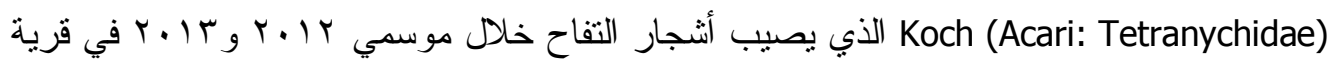
دار اوة مركز أثنمون محافظة المنوفية وكذلك تقدير التغييرات الكيميائية الحيوية للحشر ات المعاملة. أوضحت النتائج أن أعلي نسب إنخفاض في تعداد الأطوار المتحركة للعنكبوت الأحمر الأوربي أثناء

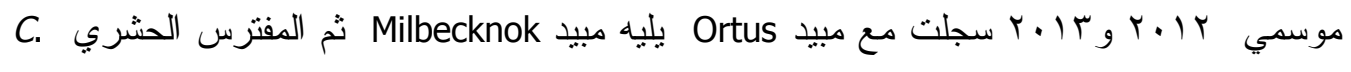

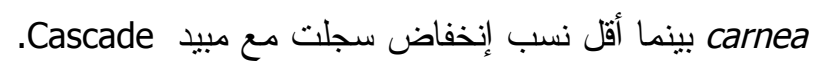

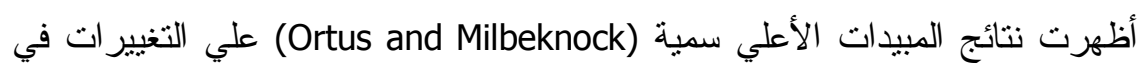
المكونات الكيميائية الحيوية لإناث العنكبوت الأحمر الأوربي، أن مبيد Ortus أحدث تغير ا كبير ا في محتوي اللبيدات الكلية والأنزيمين Acetylcholinesterase and Glutathione-S-transferase. بينما مبيد وني Milbecknok سجل تأثير ا عاليا علي كل من محتوي اللبيدات و الكربو هبدرات الكلية

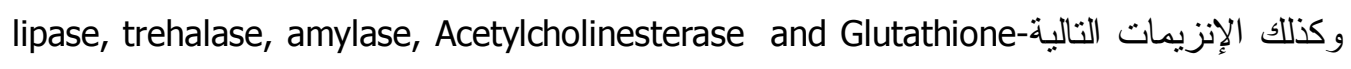

S-transferase

نستخلص من النتائج السابقة أن نوعين من الثلاثة أنو اع من المبيدات الأكاروسية لهما تأثير فعال في مكافحة العنكبوت الأحمر الأوربي علي أثنار التفاح وأن تقسير هذا يمكن إرجاعه إلي ني

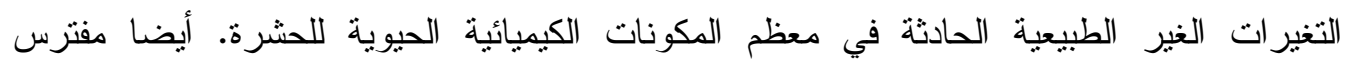
الحشرات Carnea ذو كفاءة إفتر اسية عالية ضد العنكبوت الأحمر الأوربي وينتج عن ذلك زيادة في إنخفاض تعداد العنكبوت. 